\title{
Customer Brand Loyalty towards Corporate Retail Store - [A case study of Big Bazaar retail store in Bangalore city]
}

\author{
Marri Sreenivasulu ${ }^{(1)}$, Dr. G. Janardhana M.com B. 1., Ph.D ${ }^{(2)}$ Dr. Mamilla \\ Rajasekhar $^{(3)}$ \\ I(Dept., of Commerce, Govt. Degree College Rayachoty, Kadapa district, AP. Inia) \\ ${ }^{2}$ (Dept., of commerce, Sree Venkateswara. University, Inia.) \\ ${ }^{3}$ (Dept. of Commerce, Sree Venkateswara University, Inia)
}

\begin{abstract}
Brand loyalty is the consumer's emotionally-charged decision to purchase a specific brand again and again. Recent studies focused on loyalty concept in goods as well as services sector. Of late brand loyalty is receiving a great deal of attention in corporate retailing sector. So there is a need for introducing comprehensive brand loyalty model for this retail sector. The present study is taken up with an objective to measure the opinion on the antecedents of brand loyalty such as product quality, price, purchase decision, perceived quality, store environment and design; to assess the customer satisfaction; and to suggest specific steps to improve brand loyalty towards Big Bazaar in Bangalore city is chosen through the judgment sampling method, and 100 samples are considered to pool up the opinions by convenience sampling through a well structured questionnaire. The survey results depicted that brand loyalty towards Big Bazaar is positive and all the six antecedents have the significant effect on customer satisfaction as customer satisfaction is positively associated with brand loyalty. So, it is important for a marketing manager to introduce innovative customer loyalty programs for protecting the customers' base line for Big Bazaar in Bangalore city.
\end{abstract}

Keywords: Brand Loyalty, Customer Satisfaction, Corporate Retailing Sector, Big Bazaar.

\section{Introduction}

Retailing means selling products in small volumes directly to individuals and it is emerging as a sunrise industry in India. It is presently the largest employer after agriculture and it generates more than 10\% of GDP in India ${ }^{(1)}$. The customer satisfaction and brand loyalty are pre-eminent. The success of the retail stores depends on customer's reaction to the retailing mix to earn more profits, to increase the volume of turnover, market share, image, status and lastly its survival ${ }^{(2)}$. In 2004, the Higher Court of Delhi defined the term "Retail" as a sale for final consumption in contrast to a sale for further sale or processing (i.e. wholesale), a sale to the ultimate consumer. (Higher Court of Delhi).

Retailing includes all the activities in selling goods or services directly to final consumer for personal, non-business use. A retailer or retail store is any business enterprise whose sales volume comes primarily from retailing. Although most retail stores are independently owned, some are part of corporate retailing. Corporate organizations achieve economies of scale, greater purchasing power, wider brand recognition, and better-trained employees. In the past, retailers secured customer loyalty by offering convenient location, special or unique assortment of goods, greater or better services than competitors, and store credit cards. Retailers must react or risk going out of business. In the face of increased competition from discount houses and specialty store, department stores etc, supermarkets have opened larger stores, carry a larger number and variety of items, and are upgrading facilities. Today, organized retailing has become an experience characterized by comfort, style and speed.

\section{Big Bazaar}

Big Bazaar is the chain of retail stores of the big banner Pantaloon Retail (India) Ltd., with Mr. Kishore Biyani as its group CEO and MD, headquartered in Mumbai. Big Bazaar was launched in 2001 with four stores established in Calcutta, Indore, Bangalore, and Hyderabad and has been developing rapidly by spreading its wings all over India. A great deal of stores numbering 150 reliable stores have been established in 80 cities in India. The Big Bazaar has been opening innovative sections, such as electronic bazaar, food bazaar, and furniture bazaar ${ }^{(3)}$. In Bangalore city alone, there are 12 branches. Moreover, the customer friendly ambience and the organized retailing of products also make Big Bazaar one of the successful retail companies in India. It offers all time discounts and promotional avenues to its customers ${ }^{(4)}$. 


\section{Customer Satisfaction, Brand Loyalty And Its Antecedents}

Satisfaction is a consumer's post-purchase evaluation of the overall service experience (process and outcome). ${ }^{(5)}$ Zeithaml, et al. have forwarded a definition that has wider acceptability. For them satisfaction is the customer's evaluation of a product or service in terms of whether that product or service has met the customer's need and expectations. Failure to meet needs and expectations is assumed to result in dissatisfaction with the product or service.

The brand loyalty is a consumer's preference to buy a particular brand in a product category. It occurs because consumers perceive that the brand offers the right product features, image, or level of quality at the right price. True brand loyalty exists when customers have a high relative attitude toward the brand exhibited through repurchase behavior. This type of loyalty can be a great asset to the firm: customers are willing to pay higher prices, may cost less to serve and can bring in new customers to the firm (Reichheld and Sasser, 1990) ${ }^{(6)}$.

Product quality: It is explained as "fitness for use" or "capability to obligation". Customers may replicate the buying of a particular brand or shift to different brands due to the quality of the sold product.

Price: The Customers with elevated brand loyalty are ready to pay a heavy amount for their preferred brand, because they think that brands with intense prices are more valuable.

Purchase decision: It is the accepting process in which judgment and knowledge is combined to select one product in alternatives of two or more".

Perceived Quality: It is the level to which a product or service provides key customer necessities and how consistently these requirements are delivered".

Store Environment: It is extremely vital in attracting consumer buying and purchasing opinion. "If customers find the store to be vastly reachable through their shopping tour and are happy with the store's variety and services, these clients may become loyal afterwards".

Design: Brands that provide elegant package magnetize loyal consumers who are trend aware. Fashion leaders or followers genially buy or frequently acquire products from those stores that are very fashionable and trendy (12)

\section{Review Of Literature}

Lau et al; $(2006)^{(7)}$ he mentioned in his editorial that there are numerous factors which influenced consumers' brand loyalty towards a particular brand. The factors are; brand name, product quality, price, promotion and service-quality. These studies will significantly look at product quality as a feature that influences brand loyalty. Duff (2007), ${ }^{(8)}$ A research conducted by Duff “expressed the niche market in women's cosmetics, and the outcomes explored that cosmetics buyers were faltering, more fashion aware and the customers were demanding for the products which are more attractive and new designed; furthermore, consumers have an inclination to use special makeup designs for different occasions".Andotra, Neetu, Pooja $(2009),{ }^{(9)}$ The paper through the usage of canonical discriminated function, K-means clustering procedure and multidimensional scaling technique, measures the nature and extent of customer dissonance across demographic groups, clusters, and 14 brand stimuli for operationalization of existing pattern of preference and accordingly redesigning the existing bundle of brand stimuli for strategic orientation of retailers selling SSI products. Lovelock (2010) ${ }^{(10)}$ indicated that store's environment is also one of the features that might play a vital role in consumer's decision-making. On the other hand there are some of features that influence the customer assessment and satisfaction with a specific brand. The characteristics are shoppers, salespeople, store environment, noises, smells, temperature, and displays, symbols, colors and commodities. Jain Susmit (2011) ${ }^{(11)}$ says the consumer decision processes depend on the consumer behavior. Consumers are often studied because certain decisions are significantly affected by their behavior or expected actions. The research focuses on examining the impact of Jaipur consumers 'demographic variables in various types of organized food and grocery retail formats (convenient, supermarket, and hypermarket) and exploring the drivers of customer satisfaction and loyalty in Jaipur retail supermarkets. Srivastava's (2012) ${ }^{(12)}$ research project deals with the marketing strategies that are to be followed by retailers in the retail stores located in malls. The purpose of the study is to learn about the customer profiling and learning, the market placement of MAX as a brand and various competitors existing in the market. The effect of customers and the competitors on the marketing strategies adopted by the store has been studied. Further, the study deals with the various marketing strategies adopted by these retail stores which includes, tie-ups with other brands, mall branding and other promotional offers to attract the customers and improve the competitiveness.

\section{Objectives Of The Study}

1. To measure the customer opinions on the product quality, price, purchase decision, perceived quality, store environment and product design.

2. To assess the customer satisfaction towards Big Bazaar.

3. To measure customer's brand loyalty towards Big Bazaar. 


\section{Hypotheses}

This article focuses on the factors that influence consumers' brand loyalty towards a particular Retail based Big Bazaar. Based on the factors that influence brand loyalty, the following hypotheses are derived.

$>$ H1: There is a significant and positive relationship between product quality and brand loyalty in consumer retail based Big Bazaar.

$>\mathrm{H} 2$ : There is a significant and positive relationship between price and brand loyalty in consumer retail based Big Bazaar.

$>$ H3: There is a significant and positive relationship between Purchase decision and brand loyalty in consumer retail based Big Bazaar.

$>$ H4: There is a significant and positive relationship between perceived Quality and brand loyalty in consumer retail based Big Bazaar.

$>$ H5: There is a significant and positive relationship between Design and brand loyalty in consumer retail based Big Bazaar.

> H6: There is a significant and positive relationship between store environment and brand loyalty in consumer retail based Big Bazaar.

Scope of the study

\section{Research Methodology}

The study is done on Big-bazaar customers in Bangalore city.

Data sources

Primary data:

Primary data is collected from the Big-bazaar customers in Bangalore city through a well designed questionnaire.

\section{Secondary data}

Secondary data is collected from books, magazines, company reports, some websites and news papers.

Sampling unit

All the Big-bazaar customers in Bangalore city

Sampling size

100 Big-bazaar customers are taken up for the study from Bangalore city. Therefore, the data from 97 respondents were analyzed in this study.

\section{Sampling:}

In order to investigate the antecedents of brand loyalty, Bangalore city is taken up through the judgment sampling method, and 97 samples are considered to pool up the opinions by convenience sampling through a well structured questionnaire.

\section{Data collection method}

To conduct the study, primary data and secondary data are used by the researcher to analyze brand loyalty on Big -bazaar. Primary data was collected by using self administered questionnaires which were distributed to respondents who were briefed on the purpose of the study. The structure of the questionnaire is clear, easy to understand, and straightforward to ensure that the respondents could answer the questions with ease.

Table: 1 Profile of the Sample Respondents

\begin{tabular}{|c|c|c|c|c|}
\hline S.No. & \multicolumn{2}{|c|}{ Demographic Factor } & Respondents & Percentage \\
\hline \multirow[t]{2}{*}{1.} & \multirow[t]{2}{*}{ Gender } & Male & 52 & 53.6 \\
\hline & & Female & 45 & 46.4 \\
\hline \multirow[t]{4}{*}{2.} & \multirow[t]{4}{*}{ Age } & Below 25 Yrs & 42 & 43.3 \\
\hline & & 26- 35 Yrs & 46 & 47.4 \\
\hline & & $36-45$ Yrs & 2 & 2.1 \\
\hline & & Above 45 Yrs & 7 & 7.2 \\
\hline \multirow[t]{4}{*}{3.} & \multirow[t]{4}{*}{ Education } & Below Intermediate & 9 & 9.3 \\
\hline & & Under Graduate & 55 & 56.7 \\
\hline & & Master Level & 26 & 26.8 \\
\hline & & Above Master level & 7 & 7.2 \\
\hline \multirow[t]{4}{*}{4.} & \multirow[t]{4}{*}{ Occupation } & Student & 7 & 7.2 \\
\hline & & Govt. Employee & 4 & 4.1 \\
\hline & & Private Employee & 62 & 63.9 \\
\hline & & Others & 24 & 24.7 \\
\hline \multirow[t]{3}{*}{5.} & \multirow[t]{3}{*}{ Income } & Below 20,000 & 30 & 30.9 \\
\hline & & $20001-30000$ & 49 & 50.5 \\
\hline & & Above 30000 & 18 & 18.6 \\
\hline
\end{tabular}

Source: Field Survey: Respondents $\mathrm{N}=97$ 
The demographic characteristics of the respondents are shown in Table 1. The gender distribution of the respondents was quite even, with $54 \%$ male respondents and $46 \%$ female respondents. The dominant age groups of the respondents was Below 25 to 35 years (91\%), followed by 36 to 45 years (2\%), whereas above 45 years $(7 \%)$ made up the smallest group. Both are representing $9 \%$ of the respondents.

From the table it can be inferred that $64 \%$ of the respondents are private employees, $25 \%$ are other professionals, $7 \%$ are students and the remaining $4 \%$ are Govt. employees. The income of 50\% of the respondents lies between Rs 20,000 to 30,000, $30 \%$ earn between Rs 10,000 and 20,000, 9\% earn above Rs 40,000 and the remaining $1 \%$ are in the range of Rs 30,000 to 40,000 .

In terms of level of education, almost $57 \%$ of the respondents belong to the under graduate level; $27 \%$ of the respondents had post graduate education, and $9 \%$ of the respondents had intermediate education. No respondent in the research study was at the secondary level or below. The result shows the relatively high educational attainment of the respondents.

\section{Data Analysis}

Descriptive analysis is used to analyze the background as well as the respondents' profiles pertaining to their evaluation of brand loyalty. The common measures such as the total, mean, variance, frequency and percentage are used to analyze the data gathered through the questionnaires. Frequencies such as mean and percentage analysis were used to obtain the factors that influenced respondents' brand loyalty.

ANOVA is an appropriate test for hypothesis testing when there are more than two groups measured on an interval scale. In this study, ANOVA is used to determine whether there is any significant relationship between independent variables (brand Loyalty, product quality, price, purchase decision, perceived quality, store environment and Design) and income and Age of the respondents. One-way ANOVA is a single-factor, fixedeffects model to compare the effects of one factor (Malhotra, 2007). ${ }^{(13)}$ This means that One-way ANOVA is used to determine the variability of the sample values by looking at how much the observation within each group varies as well as how much the group means varies.

Pearson Correlation was used as appropriate to analyze the relationship between the two variables which were interval-scaled and ratio-scaled. Furthermore, correlation coefficients reveal magnitude and direction of relationships which are suitable for hypothesis testing (Malhotra, 2007). The researcher used Pearson correlation to test six independent variables. (Product quality, Price, Purchase Decision, Perceived Quality, Store environment and Design), that influenced consumer brand loyalty and to test if a relationship existed between the independent and dependent variables.

\section{Results And Conclusions}

Reliability and Validity:Table 2 lists the Cronbach's Alpha (coefficient alpha) of each variable. All the variables show a high degree of reliability. Table 3 shows that there were seven independent variable factors of brand loyalty that were tested by the researcher through the questionnaires distributed to respondents. The Likert scale was used in the questionnaire: 1 indicates strongly disagree, 2 indicates disagree, 3 indicates neutral, 4 indicate agree and 5 indicates strongly agree. The result is derived from the highest mean score of factors based on the respondents' answers on brand loyalty.

Table 3 Ranking Factor of Brand Loyalty

\begin{tabular}{|c|c|c|c|c|}
\hline S.No & Factor of Brand Loyalty & & Mean & \\
\hline 1 & PRODUCT QUALITY & Mean & Average & Ranks \\
\hline Q6 & The brand stays longer than other brands & 3.37 & \multirow{5}{*}{3.296} & \multirow{5}{*}{4} \\
\hline Q7 & The materials used by the brand are natural & 3.31 & & \\
\hline $\mathrm{Q} 8$ & The brand has adequate color & 3.18 & & \\
\hline Q9 & The brand has superior functional quality & 3.15 & & \\
\hline Q10 & Overall satisfaction on product quality & 3.47 & & \\
\hline 2 & PRICE & & & \\
\hline Q11 & Increases of price do not prevent me from purchasing & 2.69 & \multirow{5}{*}{3.154} & \multirow{5}{*}{6} \\
\hline Q12 & The brand provides good rate for money & 3.2 & & \\
\hline Q13 & The brand we use charges fair price & 3.33 & & \\
\hline Q14 & Comparatively the brand we use charges low price & 3.23 & & \\
\hline Q15 & Overall satisfaction on price & 3.32 & & \\
\hline 3 & PURCHASE DECISION & & & \\
\hline Q16 & $\begin{array}{l}\text { While purchasing goods you consider friends' and family's } \\
\text { suggestions }\end{array}$ & 3.08 & \multirow{4}{*}{3.606} & \multirow{4}{*}{3} \\
\hline Q17 & It took me less time to purchase brand item & 3.8 & & \\
\hline Q18 & I take my own decision for the purchase of brand item & 3.88 & & \\
\hline Q19 & Would you like to purchase product from the company again? & 3.52 & & \\
\hline
\end{tabular}


Customer Brand Loyalty Towards Corporate Retail Store - [A Case Study Of Big Bazaar Retail...

\begin{tabular}{|c|c|c|c|c|}
\hline Q20 & Overall satisfaction on decision of purchase & 3.75 & & \\
\hline 4 & PERCEIVED QUALITY & & & \\
\hline Q21 & I have good expectation regarding quality of this brand & 3.82 & \multirow{5}{*}{3.286} & \multirow{5}{*}{5} \\
\hline Q22 & $\begin{array}{l}\text { The ability to perform the promised service dependably and } \\
\text { accurately }\end{array}$ & 3.16 & & \\
\hline Q23 & The willingness to help customers and to provide prompt service & 3.15 & & \\
\hline Q24 & The knowledge and courtesy & 3.44 & & \\
\hline Q25 & The provision of caring, and individualized attention to customers & 2.86 & & \\
\hline 5 & STORE ENVIRONMENT & & & \\
\hline Q26 & The brand has good store locality & 4.04 & \multirow{5}{*}{3.834} & \multirow{5}{*}{$\mathbf{1}$} \\
\hline Q27 & The brand has adequate outlets & 4.1 & & \\
\hline Q28 & The interior display is good & 3.98 & & \\
\hline Q29 & $\begin{array}{l}\text { Does this brand have an extensive stock that can cater to the needs } \\
\text { of the customers? }\end{array}$ & 3.67 & & \\
\hline Q30 & Overall satisfaction on store location & 3.38 & & \\
\hline 6 & DESIGN & & & \\
\hline Q31 & The brand provides broad range of designs & 3.64 & \multirow{5}{*}{3.742} & \multirow{5}{*}{2} \\
\hline Q32 & Designs of the brand are appropriate for me & 3.47 & & \\
\hline Q33 & Designs of the brand have unique features & 3.5 & & \\
\hline Q34 & Designs of the brand are stylish and fashionable & 3.85 & & \\
\hline Q35 & Overall satisfaction on design of brand & 4.25 & & \\
\hline
\end{tabular}

Source: Field Survey Respondents N = 97

Table 2 Reliability Analysis of Factor of Brand Loyalty

\begin{tabular}{|l|l|l|}
\hline S.No & Variables & Cronbach's Alpha \\
\hline 1 & Brand Loyalty & 0.79145 \\
\hline 2 & Product Quality & 0.86931 \\
\hline 3 & Price & 0.91175 \\
\hline 4 & Purchase Decision & 0.78337 \\
\hline 5 & Perceived Quality & 0.80460 \\
\hline 6 & Store Environment & 0.89140 \\
\hline 7 & Design & 0.90820 \\
\hline
\end{tabular}

Source: Field Survey N=97

The overall result shows that product quality is the most important factor. In the Bangalore City environment respondents particularly choose product quality as the main factor that influences them to be brand loyal customers. From this study it has been shown that the Bangalore environment is not much different because people of this place tend to choose product quality as the most important factor affecting their brand loyalty. The study conducted by Lau, M. M., Chang, M. S., Moon, K. and Liu, W. S. (2006) ${ }^{(14)}$ as noted in the previous section, shows that in the HongKong environment, Purchase Decision and Product Quality exert influence on brand loyalty of hard-core loyal costumers while promotions have more influence on brand switchers. The overall results show that Store Environment is perceived as the most important factor affecting their brand loyalty.

One-Way ANOVA analysis between the factors of brand loyalty and income level was executed. The objective of the analysis is to find out whether there is significant relationship between the variables.

Table 4 Income Level versus Factors of Brand Loyalty (One-Way ANOVA)

\begin{tabular}{|l|l|l|l|l|l|l|l|l|l|}
\hline S.No & Income & \multicolumn{2}{|l|}{ Brand Loyalty } & $\begin{array}{l}\text { Product } \\
\text { quality }\end{array}$ & Price & $\begin{array}{l}\text { Purchase } \\
\text { decision }\end{array}$ & $\begin{array}{l}\text { Perceived } \\
\text { quality }\end{array}$ & $\begin{array}{l}\text { Store } \\
\text { Enviro- } \\
\text { Nment }\end{array}$ & Design \\
\cline { 3 - 11 } & & No & Mean & Mean & Mean & Mean & Mean & Mean & Mean \\
\hline 1 & $\begin{array}{l}\text { Below } \\
20000\end{array}$ & 30 & 16.53 & 14.90 & 14.37 & 15.93 & 14.87 & 18.03 & 17.37 \\
\hline 2 & $\begin{array}{l}20001- \\
-30000\end{array}$ & 49 & 18.57 & 17.47 & 16.67 & 18.43 & 17.55 & 19.22 & 20.00 \\
\hline 3 & $\begin{array}{l}\text { Above } \\
30000\end{array}$ & 18 & 18.22 & 15.89 & 14.94 & 19.78 & 15.33 & 20.44 & 17.11 \\
\hline 4 & Total & 97 & 17.88 & 16.38 & 15.64 & 17.91 & 16.31 & 19.08 & 18.65 \\
\hline
\end{tabular}


Customer Brand Loyalty Towards Corporate Retail Store - [A Case Study Of Big Bazaar Retail...

\begin{tabular}{|l|l|l|l|l|l|l|l|l|l|}
\hline 5 & F-value & & $\mathbf{5 . 0 0 6}^{* *}$ & $\mathbf{7 . 3 2 4}^{* *}$ & $\mathbf{3 . 4 7 2}^{*}$ & $\mathbf{5 . 8 5 4}^{* *}$ & $\mathbf{6 . 7 6 6}^{* *}$ & $\mathbf{2 . 8 6}^{\Theta}$ & $\mathbf{7 . 9 6 0}^{* * *}$ \\
\hline 6. & Sig & & $\mathbf{0 . 0 0 9}$ & $\mathbf{0 . 0 0 1}$ & $\mathbf{0 . 0 3 5}$ & $\mathbf{0 . 0 0 4}$ & $\mathbf{0 . 0 0 2}$ & $\mathbf{0 . 0 6 2}$ & $\mathbf{0 . 0 0 1}$ \\
\hline
\end{tabular}

@ - Not significant *significant at 5 per cent level **significant at 1 per cent

The results of the analysis are presented in Table 4 . There are six variables that are significant which are Design (.001), product quality (.001), Perceived quality (.002), Purchase Decision (0.004) and Price (.035). In the Big-bazaar environment, the overall results show that Bangalore City people prefer Design, product quality, perceived quality, purchase decision and price as factors of brand loyalty. From these findings, Bangalore city people choose branded big bazaar, as reported by Lau et al. (2006), because they tend to prefer design of the big bazaar when making a purchase.

Table: 5 Ages versus Factors of Brand Loyalty (One-Way ANOVA)

\begin{tabular}{|c|c|c|c|c|c|c|c|c|c|}
\hline \multirow[t]{2}{*}{ S.No } & \multirow[t]{2}{*}{ Age } & \multicolumn{2}{|c|}{$\begin{array}{l}\text { Brand } \\
\text { Loyalty }\end{array}$} & \multirow{2}{*}{$\begin{array}{l}\text { Product } \\
\text { quality }\end{array}$} & \multirow{2}{*}{$\begin{array}{l}\text { Price } \\
\text { Mean }\end{array}$} & \multirow{2}{*}{$\begin{array}{l}\text { Purchase } \\
\text { decision }\end{array}$} & \multirow{2}{*}{$\begin{array}{l}\text { Perceived } \\
\text { quality }\end{array}$} & \multirow{2}{*}{$\begin{array}{l}\text { Store } \\
\text { Enviro- } \\
\text { Nment } \\
\text { Mean } \\
\end{array}$} & \multirow{2}{*}{$\begin{array}{l}\text { Design } \\
\text { Mean }\end{array}$} \\
\hline & & No & Mean & & & & & & \\
\hline 1 & $\begin{array}{ll}\text { Below } & 25 \\
\text { Yrs } & \end{array}$ & 42 & 18.98 & 17.55 & 17.02 & 18.40 & 18.33 & 19.60 & 19.50 \\
\hline 2 & 26- 35 Yrs & 46 & 16.89 & 15.48 & 14.52 & 17.13 & 14.70 & 18.37 & 18.15 \\
\hline 3 & $36-45 \mathrm{Yrs}$ & 2 & 19.00 & 17.50 & 15.50 & 17.50 & 19.00 & 20.00 & 19.00 \\
\hline 4 & $\begin{array}{ll}\text { Above } & 45 \\
\text { Yrs }\end{array}$ & 7 & 17.43 & 15.00 & 14.71 & 20.14 & 14.00 & 20.43 & 16.71 \\
\hline 5 & Total & 97 & 17.88 & 16.38 & 15.64 & 17.91 & 16.31 & 19.08 & 18.65 \\
\hline 6. & F-value & & 4.213* & $4.076 *$ & 3.078* & $1.363^{@}$ & $11.982 * *$ & $1.347^{@}$ & $1.786^{@}$ \\
\hline & Sig & & 0.008 & 0.009 & 0.031 & $0.259^{@}$ & 0.000 & 0.264 & 0.155 \\
\hline
\end{tabular}

@ - Not significant *significant at 5 per cent level **significant at 1 per cent

Table 5, shows only three variables are not significant which are Purchase Decision (.259) prices (.264) and design (0.155). Overall results show that among the three age groups are different attitudes when making purchase decisions, price and designs compared to the other variables.

\section{Hypothesis Test} loyalty.

As shown in Table 6, brand name was found to have significant positive relationship with brand

Table 6 Significance of brand loyalty factors with brand loyalty

\begin{tabular}{|c|c|c|c|c|c|c|c|}
\hline Variables & $\begin{array}{l}\text { Brand } \\
\text { Loyalt } \\
\mathrm{y}\end{array}$ & $\begin{array}{l}\text { Product } \\
\text { quality }\end{array}$ & Price & $\begin{array}{l}\text { Purchase } \\
\text { decision }\end{array}$ & $\begin{array}{l}\text { Perceived } \\
\text { quality }\end{array}$ & $\begin{array}{l}\text { Store } \\
\text { Enviro- } \\
\text { Nment } \\
\end{array}$ & Design \\
\hline $\begin{array}{l}\text { Brand } \\
\text { loyalty }\end{array}$ & 1.00 & $0.849 * *$ & $\begin{array}{l}0.894 * \\
*\end{array}$ & $0.752 * *$ & $0.887 * *$ & $761 * *$ & $\underline{437 * *}$ \\
\hline $\begin{array}{l}\text { Product } \\
\text { quality }\end{array}$ & & 1.00 & $\begin{array}{l}0.806^{*} \\
*\end{array}$ & $0.710 * *$ & $0.756 * *$ & $0.433 * *$ & $0.817 * *$ \\
\hline Price & & & 1.00 & $0.746 * *$ & $0.809 * *$ & $0.671 * *$ & $0.572 * *$ \\
\hline $\begin{array}{l}\text { Purchase } \\
\text { decision }\end{array}$ & & & & 1.00 & $0.500 * *$ & $0.671 * *$ & $0.469 * *$ \\
\hline $\begin{array}{l}\text { Perceived } \\
\text { quality }\end{array}$ & & & & & 1.00 & $0.565^{* *}$ & $0.404 * *$ \\
\hline $\begin{array}{l}\text { Store } \\
\text { Environment }\end{array}$ & & & & & & 1.00 & $0.19^{@}$ \\
\hline Design & & & & & & & 1.00 \\
\hline
\end{tabular}

*Pearson Correlation ** Significant at 0.01 level; @ -Not significant 


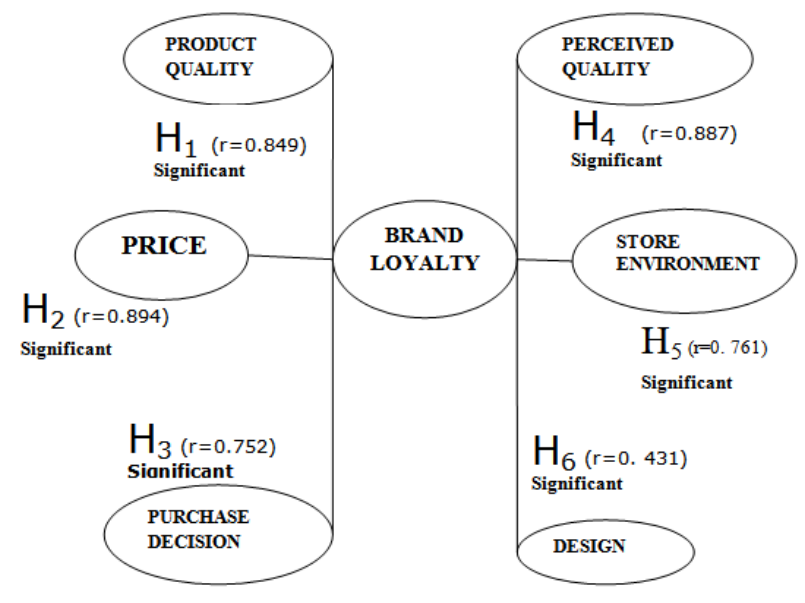

The research results showed that consumers favored brand image when they perceive positive benefits or function from the product. They would then recommend the brand, have positive reaction on the price premium and are willing to accept brand extensions to other product categories within the same brand.

Product quality was shown to have positive relationship with brand loyalty. The correlation between these two variables is shown in Table 6 . The correlation is considered a moderate correlation $(r=0.849)$ based on Cohen's (1988) guidelines. This finding indicates that product quality is significant in the consumer decision making process. The research findings showed that price and brand loyalty had a positive relationship. Price was an important consideration for the average consumer.

However, consumers with high brand loyalty were less-price sensitive. The result suggested that as long as the respondents were satisfied with a particular brand, they would repurchase the product with the perceived quality even if it was highly priced. However, the findings showed that there was relationship between perceived quality and brand loyalty. From the seven variables identified, design was another important considered factor for Bangalore people to be loyal to particular big bazaar retail super market. The results showed that purchase decision and brand loyalty were positively related.

Purchase decision was considered as one of the most important factors in determining a consumers' brand loyalty. It includes the use of advertising, sales promotion, personal selling and publicity. From the study conducted, it was seen that female respondents actually spent more time reading product labels before buying products. The finding also showed that perceived quality and brand loyalty had a positive relationship. Perceived quality was an important factor in influencing and encouraging consumers to patronize a store. The results indicated that the salesperson-consumer relationship will generally result in long-term orientation of consumers toward a store. At the same time, trust in the salesperson appeared to relate to the overall perception of the stores perceived quality which resulted in the consumer's total satisfaction with the store.

Store environment was positively related to brand loyalty. The Store environment is considered one of the factors that can influence consumer brand loyalty. From this study, it is observed that consumers paid much attention to store attributes such as merchandise display, variety of selection, parking space, easily accessible by car and the reputation of the store in purchasing products.

\section{Conclusion}

The purpose of this research is to investigate how the respondents are influenced by factors of brand loyalty towards big bazaar retail market. Brand loyalty is important for an organization to ensure that its product is kept in the minds of consumers and to prevent them from switching to other brands. The research showed that it was not easy to obtain and maintain consumer loyalty for a company's product because there were many forces drawing consumers away such as competition, consumers' needs of variety, etc. From the analysis of this study, it was shown that there are six factors of brand loyalty that were appropriate in the Bangalore city environment which are, the product quality, price, purchase decision, perceived quality, store environment and design.

The findings revealed that product quality plays a significant role in influencing consumers to be brand loyal customers. Interestingly, it is noted that this factor of product quality also plays a vital role places like Bangalore. Additionally, the overall findings of this study also show that amongst others super markets prefer product quality, price, and purchase decision, perceived quality, store environment and design as relevant factors attributable to brand loyalty. All these factors showed positive relationships with brand loyalty except 


\section{Customer Brand Loyalty Towards Corporate Retail Store - [A Case Study Of Big Bazaar Retail...}

store environment and design which had no relationship. Undeniably, the super market is one area which offers vast potential in the consumer market where there is increase in products on offer to customers. More reliable and positive findings this topic would impact on consumers, marketers and policy makers.

\section{References:}

[1]. Valarie A. Zeithml, Mary Jo Bitner, "Services Marketing” International editions 1996 pp. 75-100 and 116,117,123.

[2]. David Gilbert, "Retail Marketing Management" Sixth Impression 2009, pp.304-325.

[3]. www.bigbazaar.co.in

[4]. www.organizedretail.co.in

[5]. zeithaml V.A. and Bitner (2008), service marketing-integrating customer focus across the firm, Tata McGrawHill Publishers, 83$118,531-540$.

[6]. Reichheld, F. F. and Sasser, W. E. Jr. (1990) Zero Defections: Quality Comes to Services, Harvard Business Review, (SeptemberOctober), 105-111

[7]. Lau M.M., Chang, M.S., Moon, K., \& Liu, W.S. (2006). The brand loyalty of sportswear in Hong Kong, Journal of Textile and apparel. Technology and Management, 5, 1-13.

[8]. Duff, M. (2007), Niche marketing of cosmetics DSN Retailing today, 38, 29-35.

[9]. Andotra, Neetu, Pooja (2009), retail perspective in sub-urban markets: International journal of innovation and sustainable development 4.4: 276-293.

[10]. Lovelock, C.H. (2010). Service marketing, ( $4^{\text {th }}$ ed), new jersey: Prentice Hall.

[11]. Susmit (2011), A critical study of consumer preferences towards organized in Jaipur, international journal of research in commerce and management

[12]. Srivastava, (2012), marketing strategies adopted by retailers in retail store: a case study of max lifestyle store-phoenix mall Lucknow, international journal of research in finance and marketing 142-158.

[13]. Malhotra, N.K. (2007), marketing research, an applied orientation $5^{\text {th }}$ ed person/prentice Hall, New Jersey. 